\title{
Less than Once a Month
}

National Cancer Institute

\section{Source}

National Cancer Institute. Less than Once a Month. NCI Thesaurus. Code C129567.

An indication that something is scheduled, or occurs, less than once a month. 